\title{
THE SPATIAL DISTRIBUTION PATTERNS OF SUN-AND-BEACH TOURISM IN NON-COASTAL MUNICIPALITIES: A METHODOLOGICAL DESIGN AND APPLICATION IN THE COSTA BRAVA DESTINATION BRAND (CATALONIA, SPAIN) ${ }^{1}$
}

\author{
Josep Pueyo-Ros \\ Anna Ribas \\ Rosa M. Fraguell \\ Departamento de Geografía. Universitat de Girona \\ josep.pueyo@udg.edu ; anna.ribas@udg.edu ; rosa.fraguell@udg.edu
}

\begin{abstract}
The objective of this article was to understand the spatial distribution of sun-and-beach tourism in non-coastal municipalities. The study, which is based on the perception of accommodation managers, shows that Euclidean distance provides the best explanation for the spatial distribution of littoral tourism. We can develop a new profile of sun-and-beach tourists who search for peaceful inland lodgings in natural and rural areas. We also suspect that greening plays a role in sun-and-beach tourism, where guests search for accommodations that are close to both the sea and protected natural areas. We also showed disengagement between brand image and demand behavior.
\end{abstract}

Keywords: sun-and-beach tourism; tourism zoning; Costa Brava; tourism management; interpolation; destination brand

Fecha de recepción: marzo 2016.

Fecha de aceptación: febrero 2017.

1 This article is part of the project "Analysis of the trends and resilience strategies in use and water consumption in tourist areas. The case of Costa Brava" [number CSO2010-17488], which is funded by the Ministry of Economy and Competitiveness (Spain). Anna Ribas is the principal investigator. The Ministry of Education, Science and Sports (Spain) funds the PhD student grant to the first author [number FPU13/00663]. 


\section{RESUMEN}

El objetivo de este artículo es entender la distribución espacial del turismo de sol y playa en municipios no litorales. El estudio, basado en la percepción de los responsables de establecimientos turísticos, muestra que la distancia euclidiana ofrece la mejor explicación a la distribución espacial del turismo de sol y playa. En el estudio aparece un nuevo perfil de turismo de sol y playa que busca alojamientos tranquilos en áreas naturales o rurales del interior. Se puede intuir que la conciencia ambiental desempeña un papel importante, ya que los turistas buscan alojamientos cercanos al mar pero, a la vez, cercanos a espacios naturales protegidos. También se demuestra una disfunción entre la imagen de la marca turística y el comportamiento de la demanda.

Palabras clave: turismo de sol y playa; zonificación turística; Costa Brava; gestión turística; interpolación, marca turística.

\section{INTRODUCTION}

Sun-and-beach tourism is becoming more complex because new tourist typologies have appeared in recent years and are becoming more specialized. One example is cultural tourism, which has sub-segments, such as gastronomic tourism, wine tourism, and cinematographic tourism (Rodríguez et al., 2013). Similarly, industrial tourism has developed new sub-segments, such as energy tourism (Frantál and Urbánková, 2014). In nature tourism, more exigent sub-segments have appeared, including ecotourism (Anderson, 2009) and bird-watching (Steven et al., 2014). Complexity is caused in part by the weak distinctions among typologies. Tourism profiles also appear to be mixed, which creates new demands that cannot be met by traditional tourism offers. Demand does not end in the offer; nonetheless, the necessities and aspirations of new tourists exceed the traditional demand, the typified leisure lifestyles, and the institutionalized offers of tourism producers (Mantero, 2005). Hence, traditional sun-and-beach tourism is mixed with the profiles of new tourists who, without giving up the beach, prefer to stay further from the coast. One reason for this preference could be the avoidance of the urban and social characteristics that are associated with littoral areas. Another reason could be a growing nostalgia for landscapes and lifestyles that are hard to find in mass tourism destinations (Marín, 2009). This tourism profile produces a new pendular mobility between beach and inland accommodations that did not previously exist in traditional sun-and-beach tourism. Studying this mobility could add value to inland tourist attractions that have not yet been discovered by certain tourists. These tourists not only search for postcard beaches but can also be attracted by natural spaces, heritage sites, rural landscapes, and tiny inland villages that are between the beach and their accommodations (or close). In addition, local inhabitants lost part of their identity with the coast due to its intensive transformation, and as a consequence, the identification with inland elements has been raised (González, 2003). Hence, both tourists and local inhabitants move their gaze inland looking for culture and authenticity.

Geography defines tourism zones beyond administrative boundaries; such zones can be based on the spatial distributions of demands or on offers (Blasco et al., 2013). Thus, 
improvement of the management of resources that are not near mass tourism circuits can give less-popular attractions more visibility and value. Defining the spatial distribution patterns of sun-and-beach tourism also provides information regarding the limits of the coherence of the management concerning this new tourism profile, which until recently has been limited to the coast. Increasing knowledge of mobility patterns enables the planning of tourism services (Mckercher and Lau, 2008) that can help redefine the research and management that are based on administrative boundaries, which are often both arbitrary and relatively useless. Such knowledge can also help destinations move beyond the stagnation-decline phase of Butler's (1980) life-cycle model for tourist destinations that some authors have considered these destinations were entering beginning in the 1990s (Sardà et al., 2009).

Many studies have been conducted regarding the spatial distribution of tourism and the flows that it generates. In Spain, possibly the most representative study addresses the distribution of lodgings on the provincial scale (Pearce and Grimmeau, 1985). More recently, a study of the Catalan coast of Spain defined Homogeneous Environmental Management Units. Despite its attempt to delineate geographical areas beyond administrative boundaries, a limitation in the data forced the authors to use a county scale (Brenner et al., 2006). Similar research in Eastern Europe has also been based on administrative boundaries (Ivy and Copp, 1999). On a more detailed scale, at least one study has analyzed tourist flows in Chinese cities (Yang and Wong, 2013). Despite their geographical differences, all of these studies concluded that the distribution of tourism is unbalanced because tourists tend to remain along the coast and in large cities. Another interesting study analyzed the distribution of ecotourism in New Zealand based on tourist operators (Dickey and Higham, 2005). The results of this study revealed the rapid growth of ecotourism in coastal zones and operator-based ecotourism in urban areas. Despite the interest in the spatial distribution of tourism on a global scale, the spatial distribution of the new profile of sun-and-beach tourism has not yet been studied.

To explain tourism distribution, researchers have used many variables, most of which are related to space. In one study, the authors investigated the preferred climatic range by analyzing tourist distribution in relation to climate (Rutty and Scott, 2014). In another study that was conducted in Ghana, Adam and Amuquandoh (2013) concluded that the most influential factor in deciding where to open a hotel is the proximity to potential customers. Distance is also a key variable in the second-home market, where the distance to the main tourist settlements affects the mean number of visiting days and the ratio between owners and renters (Tjørve et al., 2013). Also using distance as a main variable, Blasco et al. (2013) defined nine tourist destinations in the Pyrenees based on the spatial distribution of tourist resources.

Nonetheless, many other studies that were not directed at tourism distribution are interesting based on their analysis of supplementary factors. Several studies have been conducted that investigated tourism preferences in choosing a beach (Lozoya et al., 2014; Oh et al., 2009). Other studies have investigated site selection in the localization of tourist services (Lo, 2012). The Hedonic Pricing Method (Rosen, 1974) has often been used to study the relation between tourism and destinations, with a focus on which variables influence accommodation prices and, thus, which variables are the most valued by tourists (Cirer Costa, 2013; Espinet et al., 2003; García-Pozo et al., 2011; Hamilton, 2007; Rigall-I-Tor- 
rent and Fluvià, 2011). In some cases, the results of these studies conflict. In a study that was performed by Cirer Costa (2013), distance appears to be insignificant, whereas in studies that were performed by García-Pozo et al. (2011) and Espinet et al. (2003), distance is the most influential spatial variable.

Destination brands are closely related to tourism distribution. The concept of a destination brand or a tourism brand has received a considerable amount of attention during the last two decades. Moreover, studies have treated marketing magazines as scientific literature (García et al., 2012; Hankinson, 2004). A destination brand is the image that is generated by a tourism destination in the minds of the customers, and a destination brand is a geographic area that is typically considered by visitors to be a single entity. Although creating a brand for a location implies respecting the historical identities of this location (Jensen, 2005), destination brands are often defined by a top-down process that follows administrative boundaries (Blasco et al., 2013). To create a successful destination brand, all focus groups must be coordinated and have the same interests (García et al., 2012). Therefore, understanding the spatial distribution patterns of tourism inside a destination brand should facilitate better brand management, which allows boundaries to be defined depending on demand and thus prevents dissonance between tourists and local residents.

In contrast, there are also some significant initiatives from institutions that define management plans beyond the administrative boundaries. In Catalonia, where Costa Brava is located, the Urbanistic Director Plan of Coastal System (Nel·lo, 2006) used a distance of 500 $\mathrm{m}$ from the coast to define the area that is subject to the plan. This distance can be extended in patches of non-urban land. Another example is the Littoral Planning of Galicia (Borobio et al., 2012), another region of Spain. The plan uses landscape criteria to delineate what should be considered as littoral, assuming the principles of the European Landscape Convention (Council of Europe, 2000) and considering all land related to sea as littoral. This plan delineated landscape units that were used as boundaries in planning.

The objective of this article was to analyze the spatial distribution of the new sun-andbeach tourism profile that chooses to stay inland - that is, in non-coastal municipalitieswithin a destination brand (in this study, Costa Brava). Our study analyzes which variables are the most influential in the localization of this new tourism profile and produces a predictive cartographic and numeric model. Finally, our study determines whether the boundaries of the destination brand are consistent with demand behavior.

\section{THE STUDY AREA}

In Catalonia (Spain), tourism represents $12 \%$ of the gross domestic product (GDP) and $15 \%$ of employment based on 82 million overnight stays per year; these statistics make Catalonia a primary global tourism destination. Tourism in Catalonia is concentrated in the coastal municipalities, which provide $80 \%$ of the region's accommodation beds and host $80 \%$ of the overnight stays (Generalitat de Catalunya, 2013). Costa Brava (Fig. 1) is one of the most popular destinations in Catalonia and depends largely on sun-and-beach tourism (Martí and Fraguell, 2007). Beach availability is an essential resource of Costa Brava (Sardà et al., 2009). However, similar to most mature coastal destinations, Costa Brava is diverting more attention inland to identify other, complementary tourism resources such 
as natural spaces, heritage sites, cultural attractions, and rural landscapes (Donaire, 1996). Thus, Costa Brava is an appropriate place to study the spatial distribution of sun-and-beach tourists who stay inland.

The Costa Brava destination brand includes three coastal counties and two inland counties that encompass an area of approximately $3,900 \mathrm{~km}^{2}$ and has a coastline that is $381 \mathrm{~km}$ in length. Costa Brava is characterized by a Mediterranean climate, with a maximum geographic altitude of 1,520 meters above sea level. Costa Brava consists of typical Mediterranean landscapes from lowlands to mid-sized mountains (Bolòs, 2001).

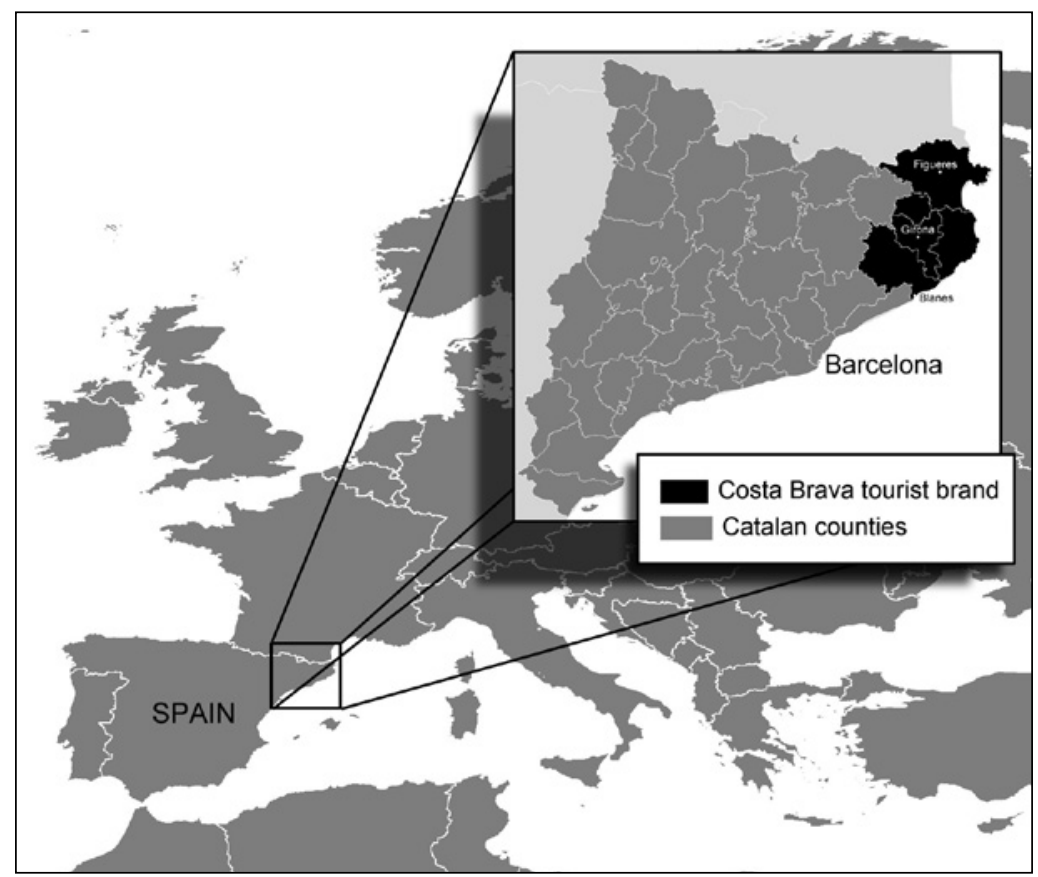

Source: Prepared by the authors on the basis of cartographic data provided by ICC and Wikimedia.

The Costa Brava region has 659,988 inhabitants (IDESCAT, data from 2014). The regional capital and main city is Girona, which consists of 97,227 inhabitants, followed by Figueres and Blanes, which include 45,444 and 39,293 inhabitants, respectively. Costa Brava has 1,344 accommodations (http://establimentsturistics.gencat.cat), which hosted 10.4 million overnight stays in 2013 by 2.9 million tourists (http://observatoriempresaiocupacio.gencat. cat). Although the coastal municipalities only represent $17 \%$ of the surface area, they contain $60 \%$ of the lodgings and $84 \%$ of the available beds for rent. This percentage of available beds is even more unbalanced for hotels: the facilities that are located in the coastal municipalities contain $87 \%$ of the beds. This trend is inverted for rural houses because coastal municipali- 
ties only account for $6.5 \%$ of the rural beds (IDESCAT, data from 2014). Thus, considerable heterogeneity exists in the distribution of tourist resources, which results in different behaviors by the coastal and inland municipalities and generates two conflicting tourism models that must coexist under a single brand.

\section{METHODOLOGY}

\section{III.1. Survey}

In this study, we employed a survey that was sent in 2014 to 548 accommodations that are located in the non-coastal Costa Brava municipalities. The survey, which was constructed by using Google $\mathbb{C}$, was sent via e-mail by using a public database that was offered by the Catalan government (http://establiments.gencat.cat). The survey comprised four questions.

1. What is the name of your accommodation?

2. What approximate percentage of your customers prioritizes going to the beach? (Please consider only summer customers)
$0 \%$
$25 \%$
$50 \% \quad 75 \%$
$100 \%$

3. What are your customers' other three main reasons for staying?

(Mark a maximum of three or add your guess.)
a. Visiting the mountains/natural areas
b. Visiting Girona and/or Figueres
c. Visiting inland villages
d. Visiting coastal natural areas
e. Visiting Barcelona
f. Other:

4. Would you like to be informed about the research results?

The answers to question three were ordered randomly to avoid a selection bias (Bethlehem, 2010). Because of the randomness of this sample, we determined whether the sample is representative of the entire population. To this end, we used Student's $t$-test to assess the significance of the distance-to-coast mean. In addition, a Chi-squared test was performed to compare the lodging typologies in the sample with the entire population; the typologies are defined in the abovementioned public database (Hotel, Rural House, Touristic apartment and Campsite).

\section{III.2. Statistical and cartographical exploration of the survey data}

The survey and accommodation data enable a statistical analysis to determine whether typology influences the percentage of sun-and-beach customers. A Kruskal-Wallis test (Kruskal and Wallis, 1952) was performed to compare the percentage of the means of each typology:

$$
\mathrm{H}_{0}: \mu_{\text {HOTEL }}=\mu_{\text {RURAL }}=\mu_{\text {APARTMENT }}=\mu_{\text {CAMPSITE }}
$$


To obtain a cartographic model of sun-and-beach tourism distribution in Costa Brava, the survey data were introduced on a GIS with the locations of the accommodations that answered the survey. The model assumes that $100 \%$ of the customers of the first-line hotels were visiting for sun-and-beach tourism. To represent this assumption on the cartographic model, a dummy lodging was created on each coastal urban area along the entire coast (65 lodgings in total).

A contour line map was created with the real and dummy accommodation data, which interpolated the percentage of customers for whom going to the beach was a priority. A Kriging algorithm (ordinary method, spherical semivariogram) that was included in the ArcGIS 10.0® software package was used to perform the interpolation. This algorithm produces better results than the Inverse distance-weighted algorithm (Zimmerman et al., 1999).

\section{III.3. Multiple linear regression model}

To construct a predictive model, the variables that could help to determine the spatial distribution of sun-and-beach tourism were used. The model was initiated based on the hypothesis that the distribution of sun-and-beach tourism can be explained by using variables that define the coastal or littoral zone. This hypothesis was based on the assumption that sun-and-beach tourists prefer littoral views during their stay. Thus, to determine which variables should be included in the model, a bibliographic review of littoral definitions was performed. We distinguished among physical variables, economic and social variables and tourist resources that were not linked to a littoral definition but were important to understand the spatial distribution of tourism.

Because distance is the most influential variable (García-Pozo et al., 2011), we used the following three measurements: (1) the Euclidean distance to the coast line; (2) the distance; and (3) the time by car to the nearest beach. Another relevant variable is altitude (Barragán, 2004). Orography, which is closely related to altitude, is also important and was represented by the slope (Barragán, 2003). Two variables that were related to slope were included in the model. The first variable expresses the slope on the point that represents the accommodation $(10 \times 10 \mathrm{~m})$; the second variable expresses the mean slope of a 500-m buffer that surrounds the accommodation. The littoral zone is linked to distance and orography and can be defined by the distance from which the sea can be seen (Barragán, 2003). Accordingly, the viewshed variable of the coastline was included in our model to express whether the coastline can be seen from the accommodation. Kay and Alder (1999) proposed a geomorphologic variable by using Holocene dunes to define the littoral zone. Thus, a variable that was included in our model is the distance from the accommodation to the nearest Holocene dune. Climatic variables (Ortega, 1992) and vegetation variables (Kay and Alder, 1999) are also closely linked to littoral zones. Because of the low level of precision regarding local climatic data, we used climate-associated vegetation as a concise variable for climatic conditions. Pinus pinea was used as the key species that defines a littoral zone because it is not only a typical Mediterranean species but also the typical tree of littoral Mediterranean landscapes. Similar to dunes, 
this variable in our model was represented by the distance from the accommodation to the nearest Pinus pinea patch. A characteristic element of a littoral zone is marine breeze (Ortega, 1992), and two variables were calculated for each lodging, namely, the number of days of breeze and the mean speed of the breeze. The winds of a NE-SE direction at 14:00 UT between June 15 and September 15 are considered marine breezes (Prohom, 1998). The data were obtained through the interpolation (Kriging algorithm, ordinary method, spherical semivariogram) of wind speed and direction, which were obtained from Catalan XEMA (automatic meteorological stations network) for 2011, 2012 and 2013 (METEOCAT, data from 2014).

Regarding the economic and social variables, one element that defines a littoral zone is infrastructure, especially the existence of certain routes (Barragán, 2003). The primary state and national roads that lead to the sea were considered in our model and were based on the distance between an accommodation and the nearest road. Social and economic characteristics were also variables that were included in our model (Barragán, 1994; Ortega, 1992) and were expressed as commercial tourist function taxes (Defert, 1967) and the percentage of a second home. The data that were available only enable the calculation of these variables on a municipal scale, which individually assumes the value of the accommodation based on its municipal location. The accommodation's price was also included in the regression model. We used the price of a double room in high season. Because prices are affected by typologies and lodging categories (Espinet et al., 2003), we also calculated the detrended price resting and the average price of each typology and category (Camping of 1st, 2nd and $3^{\text {rd }}$ categories, Touristic apartment, Rural House, Hostel and hotels with 1, 2, 3 \& 4 stars); in total, there were 10 groups. Table 1 contains a description of all included variables.

To complete the model, four variables that are not linked to littoral zones were determined. First, a variable that defines whether an accommodation is closer to Girona or Figueres (two main cities of Costa Brava) was included; relevant tourist attractions include Girona's Jewish town and Figueres's Dali Museum. Another variable expresses the Euclidean distance from an accommodation to the nearer of these two cities. Natural areas are important tourist resources in Costa Brava. Therefore, we used the Nature 2000 network ${ }^{2}$ because it is more expansive than the natural areas that receive special protection. Thus, this variable expresses the distance from the accommodation to the nearest Nature 2000 patch. The final variable represents the distance between an accommodation and the airport. The Girona-Costa Brava airport is one of the most important arrival points for international tourism in Costa Brava.

2 See the European Commission website for more information regarding the Nature 2000 network (http:// ec.europa.eu/environment/nature/natura2000/). 
Table 1

DESCRIPTION OF THE VARIABLES INCLUDED IN THE MODEL

\begin{tabular}{|c|c|c|c|c|c|}
\hline Variable & Code & Description & Mean & St. Dev. & References \\
\hline \multicolumn{6}{|c|}{ INDEPENDENT VARIABLES } \\
\hline \multicolumn{6}{|c|}{ PHYSICAL } \\
\hline Altitude & altitude & $\begin{array}{l}\text { Accommodation's altitude } \\
\text { above sea level }\end{array}$ & $160.61 \mathrm{~m}$ & $\begin{array}{l}179.89 \\
\mathrm{~m}\end{array}$ & (Barragán, 2004) \\
\hline Euclidean distance & eu.dist & $\begin{array}{l}\text { Euclidean distance from the } \\
\text { accommodation to the coastline }\end{array}$ & $21.01 \mathrm{~km}$ & $9.22 \mathrm{~km}$ & $\begin{array}{l}\text { (Espinet et al., 2003; } \\
\text { García-Pozo et al., } \\
\text { 2011) }\end{array}$ \\
\hline $\begin{array}{l}\text { Distance to Holocene } \\
\text { dunes }\end{array}$ & dunes & $\begin{array}{l}\text { Euclidean distance from the } \\
\text { accommodation to the nearest } \\
\text { Holocene dune }\end{array}$ & $16.76 \mathrm{~km}$ & $9.25 \mathrm{~km}$ & (Kay and Alder, 1999) \\
\hline Slope & slope & Accommodation's pixel slope & $3.33^{\circ}$ & $4.65^{\circ}$ & (Barragán, 2003) \\
\hline Near slope & near.sl & $\begin{array}{l}\text { Mean slope of a } 500-\mathrm{m} \text { buffer } \\
\text { around the accommodation }\end{array}$ & $4.47^{\circ}$ & $5.04^{\circ}$ & (Barragán, 2003) \\
\hline $\begin{array}{l}\text { Distance to Pinus } \\
\text { pinea }\end{array}$ & pinus & $\begin{array}{l}\text { Euclidean distance from the } \\
\text { accommodation to nearest Pinus } \\
\text { pinea patch }\end{array}$ & $4.87 \mathrm{~km}$ & $3.78 \mathrm{~km}$ & $\begin{array}{l}\text { (Kay and Alder, 1999; } \\
\text { Ortega, 1992) }\end{array}$ \\
\hline Sea visibility & sea.view & $\begin{array}{l}\text { Quantity of coastline } \\
\text { intersections in line of sight } \\
\text { with the accommodation }\end{array}$ & 2.94 & 8.35 & (Barragán, 2003) \\
\hline Days of breeze & $\begin{array}{l}\text { breeze. } \\
\text { days }\end{array}$ & $\begin{array}{l}\text { Mean (in days) in which breeze } \\
\text { is detected between } 15 / 06 \text { and } \\
15 / 09 \text { at } 14: 00 \mathrm{TU}\end{array}$ & $\begin{array}{l}41.08 \\
\text { days }\end{array}$ & $\begin{array}{l}5.02 \\
\text { days }\end{array}$ & (Ortega, 1992) \\
\hline Breeze velocity & $\begin{array}{l}\text { breeze. } \\
\text { vel }\end{array}$ & $\begin{array}{l}\text { Mean breeze velocity between } \\
15 / 06 \text { and } 15 / 09 \text { at } 14: 00 \mathrm{TU}\end{array}$ & $2.64 \mathrm{~m} \mathrm{~s}^{-1}$ & $\begin{array}{l}0.32 \mathrm{~m} \\
\mathrm{~s}^{-1}\end{array}$ & (Ortega, 1992) \\
\hline \multicolumn{6}{|c|}{ ECONOMIC AND SOCIAL } \\
\hline Second homes & homes & $\begin{array}{l}\text { Second homes/Main homes } \\
* 100\end{array}$ & $16.54 \%$ & $12.75 \%$ & $\begin{array}{l}\text { (Barragán, 1994; } \\
\text { Ortega, 1992) }\end{array}$ \\
\hline $\begin{array}{l}\text { Distance to roads to } \\
\text { the sea }\end{array}$ & roads & $\begin{array}{l}\text { Euclidean distance from the } \\
\text { accommodation to the nearest } \\
\text { road to the sea }\end{array}$ & $5.89 \mathrm{~km}$ & $5.52 \mathrm{~km}$ & (Barragán, 2003) \\
\hline Road distance & road.dist & $\begin{array}{l}\text { Distance by road from the } \\
\text { accommodation to the nearest } \\
\text { beach }\end{array}$ & $27.46 \mathrm{~km}$ & $\begin{array}{l}12.59 \\
\mathrm{~km}\end{array}$ & (Blasco et al., 2013) \\
\hline Time & time & $\begin{array}{l}\text { Time spent traveling by road to } \\
\text { the nearest beach }\end{array}$ & $32.03^{\prime}$ & 14.18 & (Blasco et al., 2013) \\
\hline $\begin{array}{l}\text { Commercial touristic } \\
\text { function tax }\end{array}$ & $\mathrm{ctft}$ & $\begin{array}{l}\text { Accommodation beds/ } \\
\text { Inhabitants }\end{array}$ & 3.79 & 5.1 & $\begin{array}{l}\text { (Barragán, 1994; } \\
\text { Defert, 1967; Ortega, } \\
\text { 1992) }\end{array}$ \\
\hline $\begin{array}{l}\text { Accommodation } \\
\text { price }\end{array}$ & price & $\begin{array}{l}\text { Price of double room in high } \\
\text { season }\end{array}$ & $70.31 €$ & $23.23 €$ & (Espinet et al., 2003) \\
\hline Detrended price & d.price & Price - Average price of group & $0.002 €$ & $20.33 €$ & (Espinet et al., 2003) \\
\hline
\end{tabular}




\begin{tabular}{|c|c|c|c|c|c|}
\hline Variable & Code & Description & Mean & St. Dev. & References \\
\hline \multicolumn{6}{|c|}{ TOURIST RESOURCES THAT ARE NOT LINKED TO A LITTORAL ZONE } \\
\hline Distance to airport & airport & $\begin{array}{l}\text { Euclidean distance from the } \\
\text { accommodation to Girona- } \\
\text { Costa Brava airport }\end{array}$ & $28.55 \mathrm{~km}$ & $\begin{array}{l}15.28 \\
\mathrm{~km}\end{array}$ & \\
\hline Distance to city & city.dist & $\begin{array}{l}\text { Euclidean distance from the } \\
\text { accommodation to the nearest } \\
\text { city (Girona or Figueres) }\end{array}$ & $14.41 \mathrm{~km}$ & $7.82 \mathrm{~km}$ & \\
\hline Nearer city & near.city & $\begin{array}{l}\text { Nearer city to the } \\
\text { accommodation }\end{array}$ & \multicolumn{2}{|c|}{$\begin{array}{l}0=\text { Girona }(n=100) \\
1=\text { Figueres }(n=71)\end{array}$} & \\
\hline $\begin{array}{l}\text { Accommodation } \\
\text { typology }\end{array}$ & typology & $\begin{array}{l}\text { Accommodation typology } \\
\text { according to the Catalan } \\
\text { government's public database }\end{array}$ & \multicolumn{2}{|c|}{$\begin{array}{l}\text { apart=touristic } \\
\text { apartment }(n=4) \\
\text { camp=campsite }(n=6) \\
\text { hotel=hotel }(n=53) \\
\text { rural=rural house } \\
(n=108)\end{array}$} & \\
\hline $\begin{array}{l}\text { Distance to Nature } \\
2000 \text { network }\end{array}$ & nat2000 & $\begin{array}{l}\text { Euclidean distance from the } \\
\text { accommodation to the nearest } \\
\text { Nature } 2000 \text { patch }\end{array}$ & $1.57 \mathrm{~km}$ & $1.42 \mathrm{~km}$ & \\
\hline \multicolumn{6}{|l|}{$\begin{array}{l}\text { DEPENDENT } \\
\text { VARIABLE } \\
\end{array}$} \\
\hline $\begin{array}{l}\text { Percentage of sun- } \\
\text { and-beach tourism }\end{array}$ & tourism & $\begin{array}{l}\text { Percentage of accommodation } \\
\text { customers for whom going to } \\
\text { the beach is the main reason for } \\
\text { the visit }\end{array}$ & $45.47 \%$ & $30.64 \%$ & \\
\hline
\end{tabular}

Source: Prepared by the authors.

Before elaborating the model, variable collinearity was tested by using Pearson's coefficient. The variables with a higher coefficient than \pm 0.9 were eliminated. We observed three variables with a Pearson's coefficient higher than \pm 0.9 , namely, eu.dist, road.dist and time. To decide which of these variables should be included in the analysis, the correlation with the tourism-dependent variable was considered, i.e., eu.dist, $r=-0.6$; road.dist, $r=-0.57$; time, $r=-0.57$. Based on these results, road.dist and time were excluded. Once collinearity was verified, the following model was generated:

$$
\begin{gathered}
\text { tourism altitude }+ \text { eu.dist }+ \text { dunes }+ \text { slope }+ \text { near. } s l+\text { pinus }+ \text { sea. } v i e w+\text { breeze. } d a y s \\
+ \text { breeze. } v e l+\text { homes }+ \text { roads }+ \text { ctf }+ \text { airport }+ \text { city. dist }+ \text { near. city } \\
+ \text { typology }+ \text { nat } 2000+\text { price }+ \text { d.price }
\end{gathered}
$$

To increase the model's functionality, the model was subjected to a process of variable elimination by using a backward/forward stepwise procedure that is based on the Akaike information criterion (Akaike, 1974).

To generate a cartographic model that is more useful and has more predictive power, atypical respondents were excluded. Linear model residuals were calculated, and all individuals with residual values in the interquartile range $\left(\mathrm{Q}_{1}: \mathrm{Q}_{3}\right)$ were extracted. These lodgings and the dummy lodgings were used to develop a new cartographic model by using the same methods as described above. 
Both of the cartographic models were compared in terms of areas and complexity by using a fractal dimension (Vila et al., 2006), which is calculated according to the following formula (Pincheira-Ulbrich et al., 2009):

$$
F D=\frac{2 \log P_{i}}{\log A_{i}}
$$

$P_{i}$ refers to the $i$ class perimeter, and $A_{i}$ refers to the $i$ class area. Fractal dimensions for the $25 \%, 50 \%$ and $75 \%$ classes were also calculated. The $0 \%$ and $100 \%$ classes were omitted because the perimeters were conditioned to study area boundaries, and the inclusion of the $0 \%$ and $100 \%$ classes could provoke a bias in the differences between the fractal dimensions of each model. Thus, the following equation was used:

$$
F D=\frac{2 \log \left(P_{25}+P_{50}+P_{75}\right)}{\log \left(A_{25}+A_{50}+A_{75}\right)}
$$

\section{RESULTS}

The survey was answered by 168 accommodations (31\% response rate), which corresponded to a $6 \%$ margin of error and a confidence interval of $95 \%$. Table 2 shows the distribution of these accommodations by lodging typologies in the sample and in the entire possible sample size.

Table 2

CLASSIFICATION BY LODGING TYPOLOGIES IN THE SAMPLE AND IN THE ENTIRE POSSIBLE SAMPLE SIZE

\begin{tabular}{|l|l|l|}
\hline & TOTAL & SAMPLE \\
\hline Hotel & 210 & 53 \\
\hline Rural house & 312 & 105 \\
\hline Campsite & 17 & 6 \\
\hline Touristic apartment & 9 & 4 \\
\hline Total & 548 & 168 \\
\hline
\end{tabular}

Source: Prepared by the authors.

Before beginning a statistical exploration of the random sample of accommodations that were obtained, we analyzed a representative sample. A Student's $t$-test was performed for eu.dist and yielded a $t$ value of 1.58, which does not satisfy the significance threshold of $\mathrm{p}<0.1$. The Kruskal-Wallis test provided a $\mathrm{p}$-value $=0.2089$. Hence, the null hypothesis cannot be rejected. Based on these results, the sample population can be considered representative of the overall population.

The survey results are shown in Table 3. 
Table 3

SURVEY RESULTS

\begin{tabular}{|c|c|c|c|c|c|c|}
\hline \multicolumn{7}{|c|}{ Which approximate percentage of your customers prioritizes going to the beach? } \\
\hline $100 \%$ & $75 \%$ & \multicolumn{2}{|c|}{\begin{tabular}{l|l}
$50 \%$ & \\
\end{tabular}} & $25 \%$ & \multicolumn{2}{|c|}{$0 \%$} \\
\hline 16 & 42 & \multicolumn{2}{|c|}{30} & 56 & \multicolumn{2}{|c|}{24} \\
\hline \multicolumn{7}{|c|}{ Show the three other main reasons for your customers' stay. } \\
\hline $\begin{array}{l}\text { Visiting Girona } \\
\text { and/or Figueres }\end{array}$ & $\begin{array}{c}\text { Visiting } \\
\text { inland towns }\end{array}$ & $\begin{array}{l}\text { Visiting } \\
\text { Barcelona }\end{array}$ & $\begin{array}{c}\text { Visiting } \\
\text { coastal natural } \\
\text { areas } \\
\end{array}$ & $\begin{array}{c}\text { Visiting } \\
\text { mountain } \\
\text { natural areas }\end{array}$ & Tranquility & $\begin{array}{l}\text { Visiting } \\
\text { coastal } \\
\text { towns }\end{array}$ \\
\hline 120 & 113 & 35 & 33 & 63 & 27 & 10 \\
\hline \multicolumn{7}{|c|}{ Would you like to be informed about the research results? } \\
\hline \multicolumn{3}{|c|}{ Yes } & \multicolumn{4}{|c|}{ No } \\
\hline \multicolumn{3}{|c|}{137} & \multicolumn{4}{|c|}{31} \\
\hline
\end{tabular}

Note that there are two options in the second question that did not appear in the original question. We included these options in the results table because they are the most frequent "Others" options. Source: Prepared by the authors.

\section{IV.1. Statistical and cartographical exploration of the survey results}

A Kruskal-Wallis test of tourism by typologies was significant with a p-value of 0.05 $(D f=3 ; K-W$ chi-squared $=11.0274 ; p$-value $=0.01158)$. Thus, the null hypothesis was rejected, and we concluded that accommodation typology has an influence on the percentage of sun-and-beach tourists who were guests at the accommodation. A graph of the means and confidence intervals of $95 \%$ by typology showed that the only couple with significant results is Rural-Hotel (Fig. 2). The mean and standard deviation results for both typologies are Hotel $\left(\bar{X}=33.96 ; S_{x}=25.04 ; n=53\right)$ and Rural $\left(\bar{X}=51.66 ; S_{x}=32.38 ; n=105\right)$. Based on these results, we concluded that in non-coastal municipalities, rural houses host an average percentage of sun-and-beach tourists that is $18 \%$ higher than that of hotels.

Figure 2

GRAPHIC OF DISTRIBUTION OF SUN-AND-BEACH TOURISM BY TYPOLOGIES

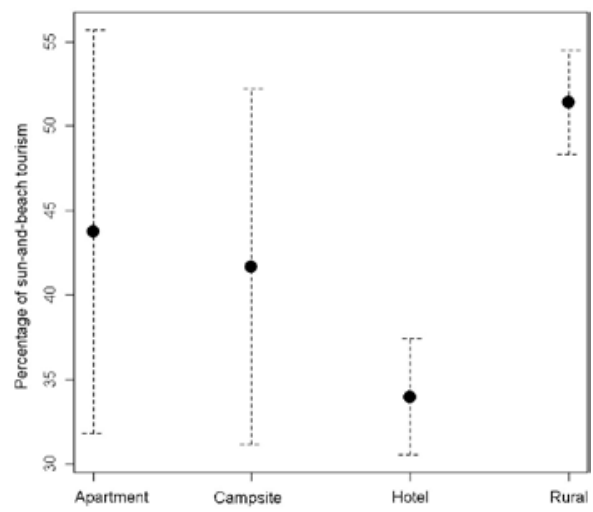

Source: Prepared by the authors. 
Figure 3 shows the spatial distribution of sun-and-beach tourism in the Costa Brava tourism destination according to our survey results. The 168 accommodations that answered the survey are shown and are classified according to typology. The spatial distribution follows a pattern with a strong link to distance to the coast.

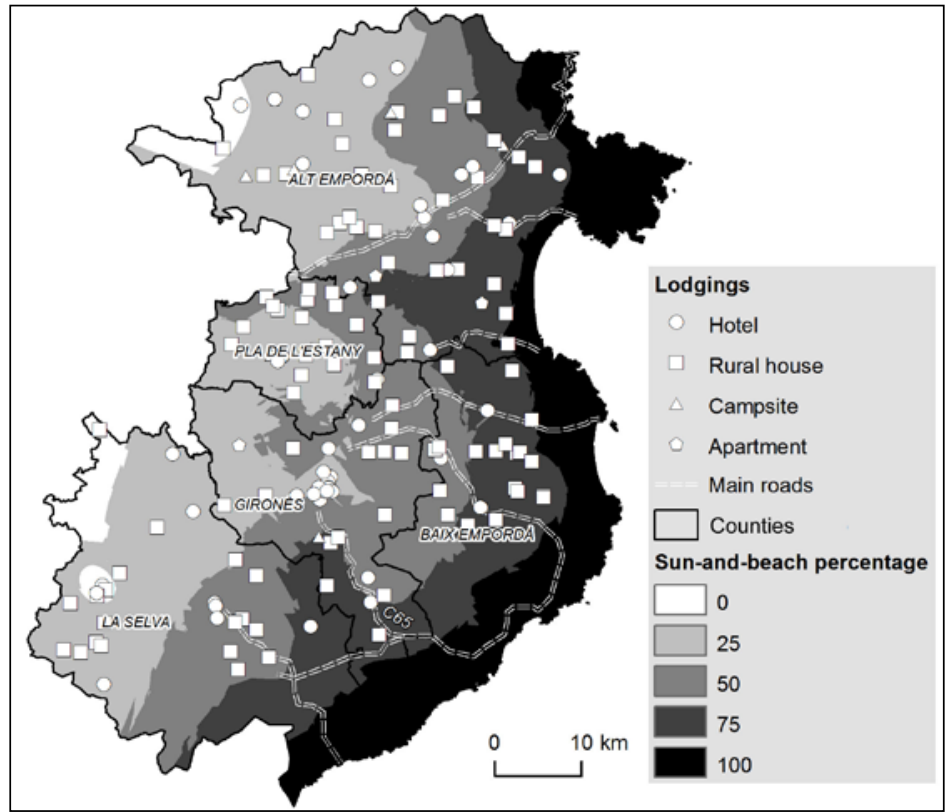

Source: Prepared by the authors on the basis of cartography provided by ICC.

\section{IV.2. Multiple linear regression model}

Table 4 shows the model that results after stepwise selection is applied. The model includes 6 variables; 3 of these variables are significant and correspond to a p-value of 0.05 . The model presents an adjustment of 0.435 . Concerning the typology variable, we used Apartment as a reference class by setting its coefficient to 0 and comparing it with the other three categories of variables.

In the second cartographic model, as mentioned above, the interquartile range values of the model residuals were used. The first and third quartile values were -14.343 and 17.338, respectively. All individual responses with values outside this range were excluded from the model, which can be seen in Figure 4. The distribution pattern is very similar to the distribution pattern of Figure 3, but the boundaries among the classes are smoother. The spatial distribution of the lodgings remains homogeneous, which suggests that atypical individual accommodations are not distributed by following a concrete pattern. If this distribution was not the case, then we would not have excluded these responses from the model. 
Table 4

MULTIPLE LINEAR REGRESSION MODEL

\begin{tabular}{|c|c|c|}
\hline & Coefficients & $\operatorname{Pr}(>|\mathrm{t}|)$ \\
\hline (Intercept) & 108.68535 & $2.62 \mathrm{e}-12 * * *$ \\
\hline Eu.dist & -1.81867 & $37 \mathrm{e}-09 * * *$ \\
\hline Airport & -0.43244 & $0.00106 * *$ \\
\hline Altitude & -0.02700 & $0.04814 *$ \\
\hline Nat2000 & -2.46866 & 0.06310 . \\
\hline d.price & 0.15711 & 0.07706 . \\
\hline Typology [T.Hotel] & -14.84204 & 0.22067 \\
\hline Typology [T.Rural] & 0.37597 & 0.97485 \\
\hline Typology [T.Campsite] & 0.35892 & 0.98087 \\
\hline \multicolumn{3}{|c|}{ Adjusted $\mathrm{R}^{2}=0.435$} \\
\hline Signif & es: ‘***’ 0.001 '**’ 0.01 & ‘*’0.05'?0.1'،1 \\
\hline
\end{tabular}

Source: Prepared by the authors.

Figure 4

SPATIAL DISTRIBUTION OF SUN-AND-BEACH TOURISM EXCLUDING ATYPICAL INDIVIDUALS IN THE MULTIPLE LINEAR REGRESSION MODEL

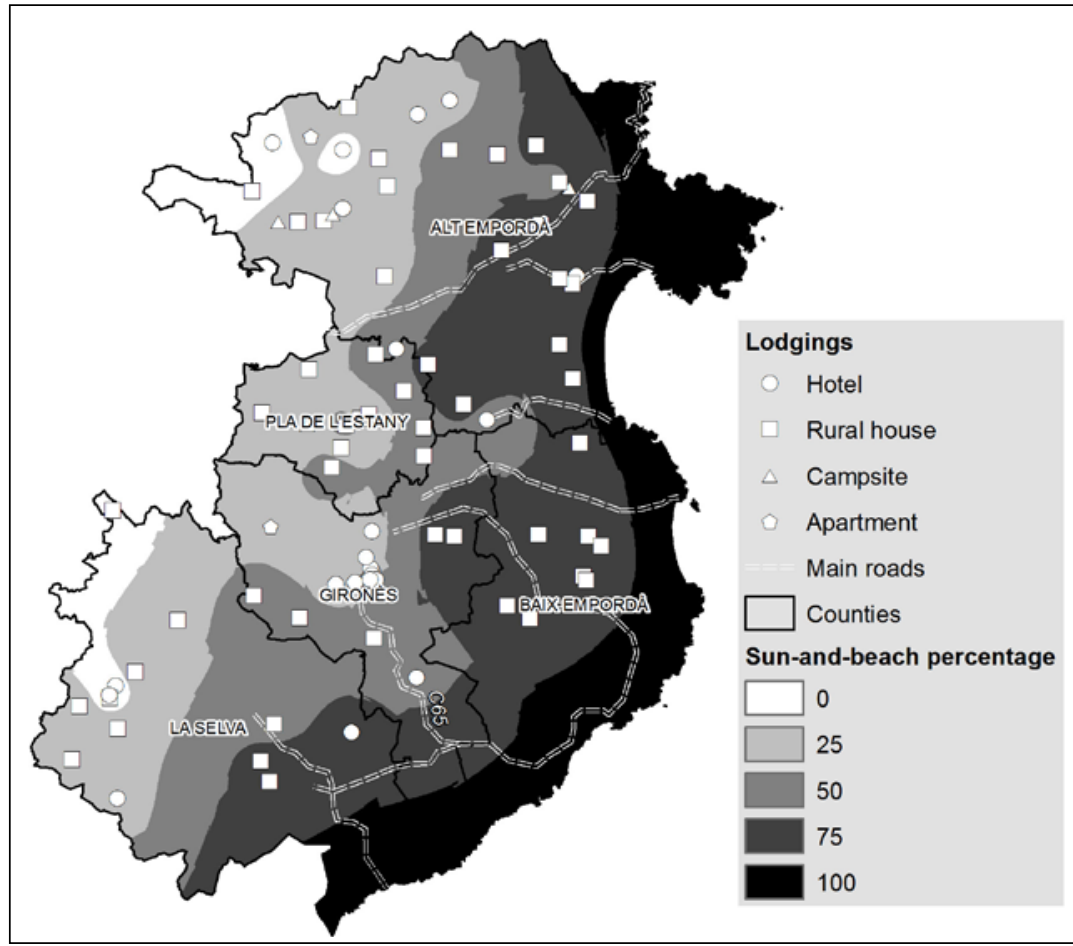

Source: Prepared by the authors on the basis of cartography provided by ICC. 
The areas and fractal dimension values of each class are represented in Table 5. The cartographic model without atypical individuals presents a lower fractal value for each class and for the entire model, which expresses a lower model complexity. The most significant differences regarding the area can be observed in the surface area increases of the $0 \%$ and $75 \%$ classes. Correspondingly, the $25 \%$ and $50 \%$ classes lose surface area, although the area that is lost occurs to a moderate extent.

Table 5

COMPARISON BETWEEN THE TWO CARTOGRAPHIC MODELS

\begin{tabular}{|c|c|c|c|c|}
\hline & All values model & $\begin{array}{c}\text { Without atypicals } \\
\text { model }\end{array}$ & Absolute difference & $\begin{array}{l}\text { Percentage } \\
\text { difference }\end{array}$ \\
\hline $100 \%$ area & 643.49 & 652.53 & 9.04 & 1.40 \\
\hline $75 \%$ area & 863.19 & 1177.84 & 314.64 & 36.45 \\
\hline $50 \%$ area & 1080.84 & 891.66 & -189.18 & -17.50 \\
\hline $25 \%$ area & 1149.42 & 952.30 & -197.12 & -17.15 \\
\hline $0 \%$ area & 123.28 & 181.74 & 58.47 & 47.43 \\
\hline $100 \% \mathrm{FD}$ & 1.88 & 1.86 & -0.02 & -4.39 \\
\hline $75 \% \mathrm{FD}$ & 1.75 & 1.61 & -0.14 & -8.00 \\
\hline $50 \% \mathrm{FD}$ & 1.79 & 1.71 & -0.08 & -4.52 \\
\hline $25 \% \mathrm{FD}$ & 1.75 & 1.70 & -0.06 & -3.15 \\
\hline $0 \% \mathrm{FD}$ & 1.99 & 1.92 & -0.07 & -3.60 \\
\hline Model FD & 1.80 & 1.72 & -0.08 & -4.55 \\
\hline
\end{tabular}

Source: Prepared by the authors.

\section{DISCUSSION}

The first relevant result was the difference in the percentage of sun-and-beach tourism between hotels and rural houses. Sun-and-beach tourism was 18\% higher in rural houses. Sun-and-beach tourists who stay in non-coastal municipalities are willing to increase their holiday mobility to avoid the problems that converge in coastal municipalities, which include noise, overcrowding, landscape degradation, and higher prices. This conclusion can be determined based on the number of accommodations where their customers look for tranquility. Rural houses offer a calm environment and authenticity as an alternative to the tourism model of hotel chains.

Figure 3 shows the spatial distribution of sun-and-beach tourism based on the interpolation of the survey results. This model shows that in two areas, sun-and-beach tourism has spread inland. The northern area coincides with the Empordà Plain, where a lack of pronounced reliefs increases the perception of a littoral landscape and facilitates the transition between the coast and the inland areas. The northern boundary of the southern area coincides with route $\mathrm{C}-65$, which is one of the main roads to the southern region of Costa Brava from Girona. This area only expands south from C-65 because the Gavarres (a littoral mountain chain) are on the north side of the road. Thus, observing the first cartographic model, we can conclude that one of the main factors in sun-and-beach tourism that expands inland is a good 
communication network. This issue is more prominent in southern Costa Brava because most crowded beaches are urban, and at these types of beaches, users prefer ready access to the beach rather than the attributes that are associated with the landscape (Lozoya et al., 2014).

In our models, we observe three points at which we can see a recoil from sun-and-beach tourism. These three points coincide with Girona, Figueres and Banyoles, which are three county capitals (Gironès, Alt Empordà and Pla de l'Estany, respectively) with important tourism attractions, such as the Dali Museum in Figueres, the Jewish town in Girona and the largest Catalan lake in Banyoles. Increased cultural tourism in these cities likely explains the decreased presence of sun-and-beach tourism (Prat and Cànoves, 2012). The Girona case is remarkable, because a peninsula-like area is drawn around Girona with higher percentages of sun-and-beach tourism to the north, south and east. Western accommodations attract a lower percentage of sun-and-beach tourism because they do not have direct access to the beach.

Our conclusions are not reflected in the regression model in which the roads and city.dist variables were excluded from the final model. In contrast, a greater distance from the airport correlates with a lower percentage of sun-and-beach tourism $(0.43 \%$ decrease per $\mathrm{km})$. As shown in the cartographic model, distance to the coast is a highly significant variable, because every $\mathrm{km}$ from the coast corresponds to a $1.8 \%$ lower percentage of sun-and-beach tourism. Although other studies have shown that distance by road has more predictive power than Euclidean distance (Blasco et al., 2013), our correlation analysis shows that Euclidean distance better explains the dependent variable's behavior than distance by road or time by road. One possible explanation for this discrepancy is the increase in online booking, where much of the planning regarding the accommodation is likely based on a digital map. Because tourists may be unfamiliar with the area, they may limit their search based on the distance from an accommodation to the coast without considering the road network or other factors.

Although price is only significant at the 0.1 level, the fact that it remained in the model indicated an importance in distribution. The model showed that as an accommodation became more expensive, more sun-and-beach-tourism occurred. Each rise of $1 €$ in price means a rise of $0.15 \%$ of sun-and-beach-tourism. Although this is a small increment, it is important to analyze it because there is no apparent reason that sun-and-beach tourists prefer more expensive accommodations. Although previous studies showed that distance-to-coast is one of the most influential variables in accommodation prices in coastal municipalities (García-Pozo et al., 2011), our study demonstrated that distance is not relevant to the prices in non-coastal municipalities (the correlations with Euclidean distance are 0.08 for price and 0.06 for detrended price). We can conclude that the prices in non-coastal municipalities are affected by factors other than distance. Applying a hedonic pricing study could be interesting to determine which factors are relevant to accommodation prices. Another important characteristic of accommodations is the number of beds. Although considering how the size of accommodation influences the percentage of sun-and-beach tourism would be interesting, this analysis goes beyond the scope of the study.

Distance to Nature 2000 areas is also significant at the 0.1 level, which is a type of greened sun-and-beach tourism that guests in non-coastal municipalities can deduce. A location that is closer to natural areas correlates with a higher percentage of sun-and-beach tourism. This result is coherent with the ANOVA results, because green tourists tend to prefer rural houses (Albaladejo-Pina and Díaz-Delfa, 2009). 
The second cartographic model, which includes only accommodations that best fit the regression model, allows for a simplified map of the spatial distribution without substantially changing the proportions of the classes. This map respects the idiosyncrasies that were commented on concerning the previous model, but this model has softer lines and less abrupt changes. In this model, an increase in the zone of the $75 \%$ class can be observed at the expense of the $50 \%$ class. Most of this difference occurs in Baix Empordà County, where most of the accommodations that defined the $50 \%$ class in the area were excluded in the second model. Notably, a disadvantage that is associated with the functionality of this simplified model is the less accurate reflection of the survey results, because the exclusion of atypical individuals was based on a model that explains the $43 \%$ variance in the spatial distribution. Thus, the second simplified model was neither better nor worse than the first model, because both models serve different functions. The second model is likely more useful for zoning or making tourism-based predictions. However, the first model enables a more exhaustive analysis of the spatial distribution patterns of sun-and-beach tourism.

The qualities of sun-and-beach tourism can be observed from the results that typical behaviors are valid, such as the proximity to coast being the most influential factor in choosing lodging. Conversely, new behaviors can be extracted from the results that are not typical of sun-and-beach tourism. Sun-and-beach tourists who stay inland tend to search for calm locations and prefer rural houses to hotels. In addition, we observed "greening," or searching for accommodations in proximity to the beach and natural areas.

Without differentiating between the image and the personality of a destination brand (Pereira et al., 2012), the Costa Brava brand projects a single image that relates to sunand-beach tourism. Although previous studies were dedicated to the regionalization of the Catalan coast and included three counties of Costa Brava in the same group (Brenner et al., 2006), our results suggest that the Costa Brava brand presents two spatially different personalities, namely, coastal and inland. Although the coast attracts more sun-and-beach tourism, which fits the brand image, this tourism segment decreases in a correlative manner with distance from the coast until sun-and-beach tourism becomes non-existent. This disengagement can result in development limitations inland because if a brand focuses too much on a single element, vision and action can be restricted and circumscribed and can limit alternative developments to the model that is projected by the brand (Stern and Hall, 2010). This brand dysfunction is caused by an arbitrary delineation of tourism destinations based on county boundaries that do not agree with actual tourist behavior. This difference causes inland municipalities and businesses to base their attractions in nature and mountain activities on littoral-centered tourist agencies. Our results show the need to revise destination boundaries to improve management and promote the development of all tourism segments that coexist in the Costa Brava region.

\section{CONCLUSIONS}

The objective of this paper was to analyze the spatial distribution patterns of sun-andbeach tourism in non-coastal municipalities and to identify the variables that may influence the distribution of sun-and-beach tourists. The method that was used in our study allows for both graphical and numerical results by using cartographical and linear regression models. 
With our results, we created a map to illustrate the spatial distribution of sun-and-beach tourism by using two methods. The first model contains the raw data, and the second model was based on a residual analysis of the regression model, which sacrifices accuracy but is more useful because it shows more defined areas.

One of the most relevant advantages of our research method is the fact that our study is based on a concise survey of only three questions (the model only uses one question). All other variables were obtained by using public cartography or by visiting websites. The design of the survey likely contributed to the high rate of survey responses, which provides an adequately sized sample for our analysis. Although this method presented benefits, it had also limitations. The most important limitation is the fact that the distribution pattern had to be based on the perception of accommodation managers. Thus, we assumed that the managers knew the habits of their customers well enough to answer the questions in a rigorous way. Moreover, most studies that analyze spatial distribution are either based on administrative boundaries (Brenner et al., 2006; Dickey and Higham, 2005; Ivy and Copp, 1999; Pearce and Grimmeau, 1985) or are limited to urban areas (Yang and Wong, 2013). Our study analyzes accommodations on a regional scale and goes beyond the administrative boundaries. Thus, our method is useful for determining regional zoning boundaries based on demand without being conditioned by administrative boundaries. Moreover, this study is effective for the analysis of the spatial distribution of a tourism segment and the variables that may influence this segment.

Based on the effectiveness of the resulting model in our analysis of the spatial distribution patterns of sun-and-beach tourism and our analysis of the boundaries of a concrete destination brand, additional similar studies on other mature coastal destinations would be interesting. Our results should be tested to determine whether sun-and-beach tourist behavior can be generally applied to other destinations or whether our results are only applicable to Costa Brava. In addition, it would be interesting to analyze other destination brands to determine whether they also demonstrate disengagement between their administrative boundaries and the actual spatial distribution of different tourism segments.

\section{REFERENCES}

ADAM, I., and AMUQUANDOH, F. E. (2013). «Hotel characteristics and location decisions in Kumasi Metropolis, Ghana». Tourism Geographies, 16(4), 653-668. http://doi.org/10 $.1080 / 14616688.2012 .762689$

AKAIKE, H. (1974). «A new look at the statistical model identification». IEEE Transactions on Automatic Control, 19(6), 716-723. http://doi.org/10.1109/TAC.1974.1100705

ALBALADEJO-PINA, I. P., and DÍAZ-DELFA, M. T. (2009). «Tourist preferences for rural house stays: Evidence from discrete choice modelling in Spain». Tourism Management, 30(6), 805-811. http://doi.org/10.1016/j.tourman.2009.01.001

ANDERSON, W. (2009). «Promoting ecotourism through networks: case studies in the Balearic Islands». Journal of Ecotourism, 8(1), 51-69. http://doi. org/10.1080/14724040802140584

BARRAGÁN, J. M. (1994). Ordenación, planificación y gestión del espacio litoral. Barcelona: Oikos-tau. 
BARRAGÁN, J. M. (2003). Medio ambiente y desarrollo en áreas litorales : introducción a la planificación y gestión integradas. Cádiz: Universidad de Cádiz.

BARRAGÁN, J. M. (2004). Las áreas litorales de España: del análisis geográfico a la gestión integrada. Nimbus: Revista de climatología, meteorología y .... Madrid: Ariel.

BETHLEHEM, J. (2010). «Selection Bias in Web Surveys». International Statistical Review, 78(2), 161-188. http://doi.org/10.1111/j.1751-5823.2010.00112.x

BLASCO, D., GUIA, J., and PRATS, L. (2013). «Tourism destination zoning in mountain regions: a consumer-based approach». Tourism Geographies, 16(3), 512-528. http://doi. org/10.1080/14616688.2013.851267

BOLÒS, O. de. (2001). La Vegetació dels Països Catalans. Terrassa : Aster.

BOROBIO, M., GARCÍA, M., CASTILLO, F., and PAYÁN, M. (2012). «La sostenibilidad como principio rector de la ordenación territorial en Galicia. Las Directrices de ordenación del territorio y el Plan de Ordenación del Litoral». REGAP: Revista Galega de Administración Pública, (44), 333-354.

BRENNER, J., JIMENEZ, J. A., and SARDÁ, R. (2006). «Definition of Homogeneous Environmental Management Units for the Catalan Coast». Environmental Management, 38(6), 993-1005. http://doi.org/10.1007/s00267-005-0210-6

BUTLER, R.W. (1980). «The concept of a tourist area cycle of evolution: implications for management of resources.». Canadian Geographer.

CIRER COSTA, J. C. (2013). «Price formation and market segmentation in seaside accommodations». International Journal of Hospitality Management, 33, 446-455. http://doi. org/10.1016/j.ijhm.2012.11.004

COUNCIL OF EUROPE (Ed.). (2000). European landscape convention. inproceedings, Florence.

DEFERT, P. (1967). Le taux de fonction touristique: mise au point et critique. BOOK, Marseille: Université d'Aix-Marseille, Centre d'études du tourisme, Institut d'administration des entreprises.

DICKEY, A., and HIGHAM, J. E. S. (2005). «A Spatial Analysis of Commercial Ecotourism Businesses in New Zealand: A c 1999 Benchmarking Exercise Using GIS». Tourism Geographies, 7(4), 373-388. http://doi.org/10.1080/14616680500291170

DONAIRE, J. A. (1996). El Turismo a los ojos del postmodernismo : una lectura desde la dialéctica socioespacial : la Costa Brava, Tunicia y los malls. Universitat Autònoma de Barcelona, Barcelona.

ESPINET, J. M., SAEZ, M., COENDERS, G., and FLUVIÀ, M. (2003). «Effect on prices of the attributes of holiday hotels : a hedonic prices approach». Tourism Economics, 9(2), 165-177.

FRANTÁL, B., and URBÁNKOVÁ, R. (2014). «Energy tourism: An emerging field of study». Current Issues in Tourism, 1-18. http://doi.org/10.1080/13683500.2014.987734

GARCÍA, J. A., GÓMEZ, M., and MOLINA, A. (2012). «A destination-branding model: An empirical analysis based on stakeholders». Tourism Management, 33(3), 646-661. http:// doi.org/10.1016/j.tourman.2011.07.006

GARCÍA-POZO, A., SÁNCHEZ-OLLERO, J. L., and MARCHANTE-LARA, D. M. (2011). «Applying a hedonic model to the analysis of campsite pricing in spain». International Journal of Environmental Research, 5(1), 11-22. 
GENERALITAT DE CATALUNYA (2013). Pla estratègic de turisme de Catalunya 2013 2016 i Directrius nacional de turisme 2020. Barcelona.

GONZÁLEZ, J. M. (2003). «La pérdida de espacios de identidad y la construcción de lugares en el paisaje turístico de Mallorca». Boletín de La Asociación de Geógrafos Españoles, 35, 137-152.

HAMILTON, J. M. (2007). «Coastal landscape and the hedonic price of accommodation». Ecological Economics, 62(3-4), 594-602. http://doi.org/10.1016/j.ecolecon.2006.08.001

HANKINSON, G. (2004). «Relational network brands: Towards a conceptual model of place brands». Journal of Vacation Marketing, 10(2), 109-121. http://doi. org/10.1177/135676670401000202

IVY, R. L., and COPP, C. B. (1999). «Tourism patterns and problems in East Central Europe» . Tourism Geographies, 1(4), 425-442. http://doi.org/10.1080/14616689908721335

JENSEN, O. B. (2005). «Branding the contemporary city-urban branding as regional growth agenda». In Plenary paper for Regional Studies Association Conference. Aalborg: Aalborg University. inproceedings.

KAY, R. C., and ALDER, J. (1999). Coastal Planning and Management. London: E \& FN Spon.

KRUSKAL, W. H., and WALLIS, W. A. (1952). «Use of Ranks in One-Criterion Variance Analysis». Journal of the American Statistical Association, 47(260), 583-621. JOUR. http://doi.org/10.2307/2280779

LO, H.-H. (2012). «Site Selection Criteria for Coastal Tourism Facilities». 2012 International Symposium on Computer, Consumer and Control, (3), 272-277. http://doi.org/10.1109/ IS3C.2012.75

LOZOYA, J. P., SARDÀ, R., and JIMÉNEZ, J. A. (2014). «Users expectations and the need for differential beach management frameworks along the Costa Brava: Urban vs. natural protected beaches». Land Use Policy, 38, 397-414. http://doi.org/10.1016/j.landusepol.2013.12.001

MANTERO, J. C. (2005). «Turismo: ética y desarrollo». ALCUTH, 4, 7-20.

MARÍN, R. G. (2009). «Turismo, urbanización y estilos de vida: Las nuevas formas de movilidad residencial». Cuadernos de Turismo, (24), 289-291.

MARTÍ, C., and FRAGUELL, R. M. (2007). La Costa Brava. [Girona] : Fundació Caixa Girona.

MCKERCHER, B., and LAU, G. (2008). «Movement Patterns of Tourists within a Destination». Tourism Geographies, 10(3), 355-374. http://doi.org/10.1080/14616680802236352

NEL·LO, O. (2006). «El Pla director urbanístic del litoral de Catalunya (PDUSC)». Espais.

OH, C.-O., DRAPER, J., and DIXON, A. W. (2009). «Assessing Tourists’ Multi-Attribute Preferences for Public Beach Access». Coastal Management, 37(2), 119-135. http://doi. org/10.1080/08920750802701128

ORTEGA, F. (ED.). (1992). La Ordenación del litoral : XVI semana de estudios superiores de urbanismo. Granada: Centro de Estudios Municipales y de Cooperación Interprovincial.

PEARCE, D., and GRIMMEAU, J. (1985). «The spatial structure of tourist accommodation and hotel demand in Spain». Geoforum, 16(1), 37-50.

PEREIRA, R. L. G., CORREIA, A. L., and SCHUTZ, R. L. A. (2012). «Destination Branding: A Critical Overview». Journal of Quality Assurance in Hospitality \& Tourism, 13(April), 81-102. http://doi.org/10.1080/1528008X.2012.645198 
PINCHEIRA-ULBRICH, J., RAU, J., and PEÑA-CORTÉS, F. (2009). «Tamaño y forma de fragmentos de bosque y su relación con la riqueza de especies de árboles y arbustos». Phyton, International Journal of Experimental Botany, 78, 121-128.

PRAT, J. M., and CÀNOVES, G. (2012). «El turismo cultural como oferta complementaria en los destinos de litoral . El caso de la Costa Brava (España)». Investigaciones Geográficas, (79), 119-135.

PROHOM, M. J. (1998). «Principales características de la brisa marina estival en un punto de la costa catalana: Sant Pere Pescador». In Coloquio del Grupo de Métodos Cuantitativos, Sistemas de Información Geográfica y Teledetección. VIII (pp. 167-179).

RIGALL-I-TORRENT, R., and FLUVIÀ, M. (2011). «Managing tourism products and destinations embedding public good components: A hedonic approach». Tourism Management, 32(2), 244-255. http://doi.org/10.1016/j.tourman.2009.12.009

RODRÍGUEZ, M. L., FRAIZ, J. A., and ALÉN, M. E. (2013). «New segments for cultural tourism. An approach to traveler film tourism behavior». Cuadernos de Turismo, (32), 259-279.

ROSEN, S. (1974). «Hedonic Prices and Implicit Markets : Product Differentiation in Pure Competition». Journal of Political Economy, 82(1), 34-55.

RUTTY, M., and SCOTT, D. (2014). «Thermal range of coastal tourism resort microclimates». Tourism Geographies, 16(3), 346-363. http://doi.org/10.1080/14616688.2014.932833

SARDÀ, R., MORA, J., ARIZA, E., AVILA, C., and JIMENEZ, J. A. (2009). «Decadal shifts in beach user sand availability on the Costa Brava (Northwestern Mediterranean Coast)». Tourism Management, 30(2), 158-168. http://doi.org/10.1016/j.tourman.2008.05.011

STERN, P., and HALL, P. V. (2010). «Historical limits: Narrowing possibilities in "Ontario"s most historic town'». Canadian Geographer, 54(2), 209-227. http://doi.org/10.1111/ j.1541-0064.2009.00296.x

STEVEN, R., MORRISON, C., and CASTLEY, J. G. (2014). «Birdwatching and avitourism: a global review of research into its participant markets, distribution and impacts, highlighting future research priorities to inform sustainable avitourism management». Journal of Sustainable Tourism, 1-20. http://doi.org/10.1080/09669582.2014.924955

TJØRVE, E., FLOGNFELDT, T., and TJØRVE, K. M. C. (2013). «The Effects of Distance and Belonging on Second-Home Markets». Tourism Geographies, 15(2), 268-291. http:// doi.org/10.1080/14616688.2012.726264

VILA, J., VARGA, D., LLAUSÀS, A., and RIBAS-PALOM, A. (2006). «Conceptos y métodos fundamentales en ecología del paisaje (landscape ecology). Una interpretación desde la geografía». Documents d'Anàlisi Geogràfica, 48, 151-166.

YANG, Y., and WONG, K. K. F. (2013). «Spatial Distribution of Tourist Flows to China's Cities». Tourism Geographies, 15(2), 338-363. http://doi.org/10.1080/14616688.2012.6 75511

ZIMMERMAN, D., PAVLIK, C., RUGGLES, A., and ARMSTRONG, M. P. (1999). «An experimental comparison of ordinary and universal kriging and inverse distance weighting». Mathematical Geology, 31(4), 375-390. JOUR. 
